\title{
Neurotrophin-3 Promotes the Differentiation of Muscle Spindle Afferents in the Absence of Peripheral Targets
}

\author{
Robert A. Oakley, ${ }^{1}$ Frances B. Lefcort, ${ }^{2,5}$ Douglas O. Clary, ${ }^{4,5}$ Louis F. Reichardt, ${ }^{5}$ David Prevette, ${ }^{3}$ \\ Ronald W. Oppenheim, ${ }^{3}$ and Eric Frank ${ }^{1}$ \\ ${ }^{1}$ Department of Neurobiology, University of Pittsburgh, School of Medicine, Pittsburgh, Pennsylvania 15261, ${ }^{2}$ Department \\ of Biology, Montana State University, Bozeman, Montana 59717, ${ }^{3}$ Department of Neurobiology and Anatomy and \\ Neuroscience Program, Bowman Gray School of Medicine, Wake Forest University, Winston-Salem, North Carolina \\ 27157, 4 Sugen Inc., Redwood City, California 94063, and 5Department of Physiology and Howard Hughes Medical \\ Institute, University of California, San Francisco, California 94143
}

The neurons of the dorsal root ganglia (DRG) that supply muscle spindles require target-derived factors for survival. One necessary factor for these neurons is neurotrophin-3 (NT3). To determine whether NT3 can promote the survival of these neurons in the absence of other target-derived factors, we analyzed the effects of exogenous NT3 after early limb bud deletion in the chick. In control embryos, limb bud deletion eliminated $\sim 90 \%$ of the trkC-positive (trkC+) neurons in lumbar DRG on the deleted side. In addition, the deletion led to a dramatic loss of collateral sensory projections to motoneurons. Exogenous NT3 restored a normal population of trkC+ neurons in lumbar DRG on the deleted side and increased the number of trkC + neurons in DRG with normal targets (contralateral lumbar and thoracic). The effect was highly selective; NT3 increased the number of trkC+ neurons without significantly changing the number of either trkA + or trkB + neurons. The effect of NT3 was attributable to the rescue of DRG neurons from cell death, because exogenous NT3 reduced the number of pyknotic nuclei without significantly altering proliferation. Analysis of spinal projections showed further that many of the trkC+ neurons rescued by NT3 projected to the ventral spinal cord. These neurons thus had central projections characteristic of muscle spindle afferents. Together, our results indicate that NT3 signaling is both necessary and sufficient for the development of the proprioceptive phenotype, even in the absence of other signals from limb muscle.

Key words: neurotrophins; sensory neurons; muscle spindle afferents; survival; specification; differentiation; development; spinal cord projections; muscle
The dorsal root ganglia (DRG) are composed of several functionally diverse populations of sensory neurons that form distinct patterns of central connections within the spinal cord. For example, most DRG neurons are small-diameter cutaneous afferents (nociceptors and thermoceptors) that project to the superficial layers of the dorsal horn. In contrast, the comparatively small population of large-diameter DRG neurons that supply muscle spindles project to the ventral horn and make monosynaptic connections with motoneurons (for review, see Willis and Coggeshall, 1991; also see Ruit et al., 1992). Thus, different populations of sensory neurons have distinct identities that can be defined on the basis of their central and peripheral projections.

Developmental studies in the frog have shown that the identity of sensory neurons is dependent on their peripheral targets, in that the peripheral target can determine the pattern of central connections. For example, if thoracic DRG, which normally lack any muscle spindle afferents, are forced to supply forelimb muscles, these ganglia will produce muscle spindle afferents that

Received Nov. 4, 1996; revised Feb. 27, 1997; accepted March 7, 1997.

This work was supported by National Institutes of Health Grants NS24373 (E.F.), NS20402, and NS31380 (R.W.O.). R.A.O. was supported by a fellowship from the Muscular Dystrophy Association. L.F.R. is an investigator of the Howard Hughes Medical Institute (HHMI). For a portion of this work, F.B.L. and D.O.C. were supported as Associates by HHMI. We also thank Dr. Ron Lindsay and Regeneron Pharmaceuticals Inc. for generously providing NT3.

Correspondence should be addressed to Dr. Eric Frank, Department of Neurobiology, University of Pittsburgh, School of Medicine, 3500 Terrace Street, W1404 BST, Pittsburgh, PA 15261.

Copyright (C) 1997 Society for Neuroscience $0270-6474 / 97 / 174262-13 \$ 05.00 / 0$ project to the appropriate forelimb motoneurons (Frank and Westerfield, 1982; Smith and Frank, 1987). These results indicate that some signal(s) from peripheral targets can determine both the general identity of sensory neurons (i.e., the muscle spindle afferent phenotype) and their specific identity in terms of which motoneurons they choose as synaptic partners. One class of target-derived signaling molecules that may be involved in determining the identity of sensory neurons is the neurotrophins.

Different subpopulations of DRG neurons depend on different neurotrophins to survive the period of cell death in the DRG. Studies using function-blocking antibodies that recognize specific neurotrophins have shown that muscle spindle afferents require NT3 during this period (Oakley et al., 1995), whereas small diameter cutaneous afferents require nerve growth factor (NGF) (Ruit et al., 1992). Similarly, genetic deletion of members of the trk family of neurotrophin receptors results in the selective loss of specific DRG subpopulations. Targeted mutation of the catalytic form of trkC, a receptor for NT3, eliminates all muscle spindle afferents but spares cutaneous afferents (Klein et al., 1994). In contrast, targeted mutation of trkA or NGF eliminates smalldiameter cutaneous afferents and apparently spares muscle spindle afferents (Crowley et al., 1994; Smeyne et al., 1994; for review, see Snider, 1994). Together, these results indicate that NT3 signaling through trkC is necessary for the survival of muscle spindle afferents. These results further suggest that target tissues could, in principle, influence the identity of sensory neurons by signaling with neurotrophins. 
A.
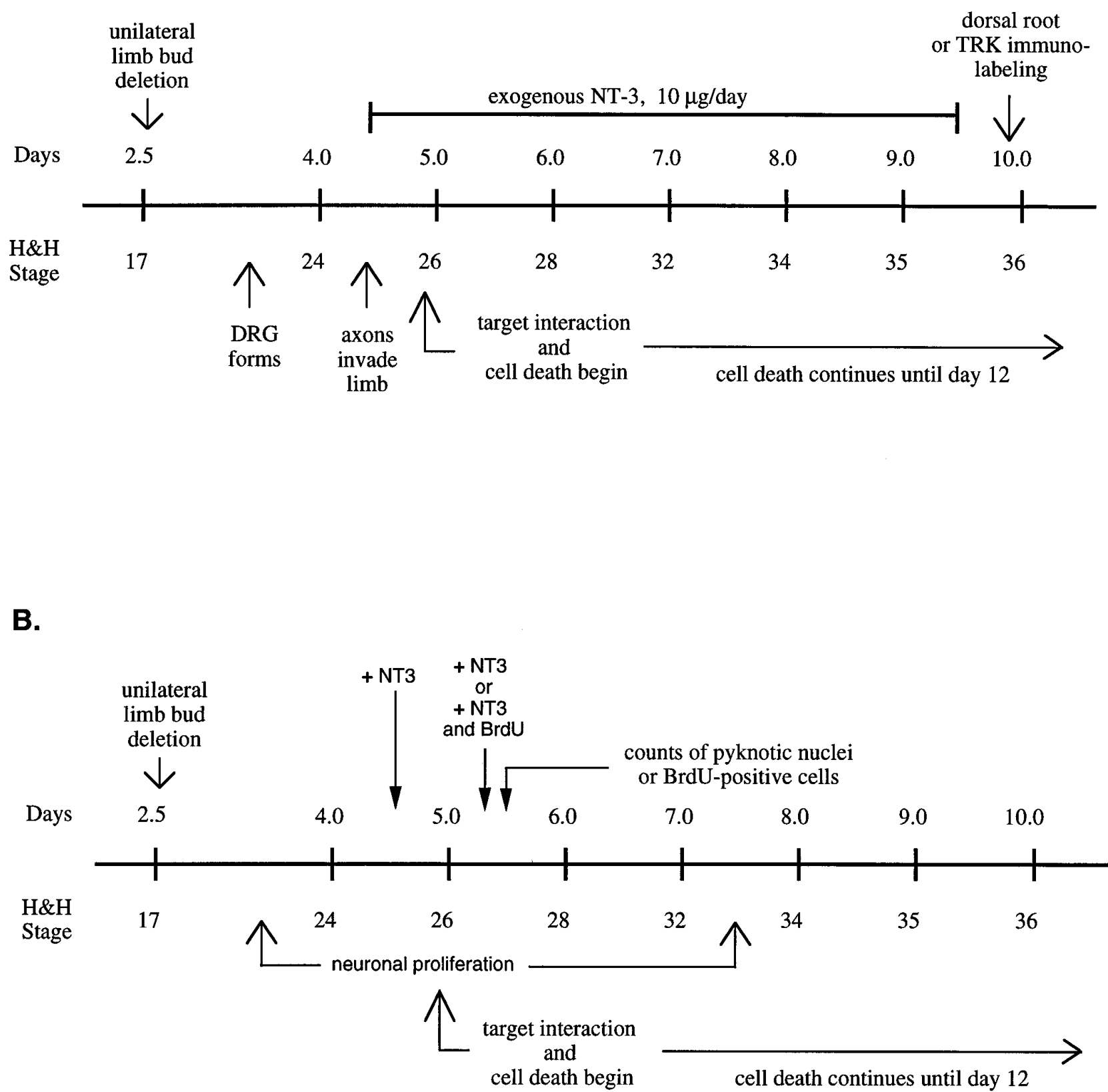

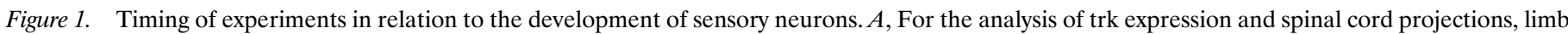

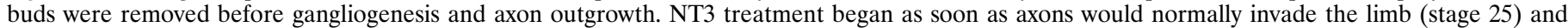

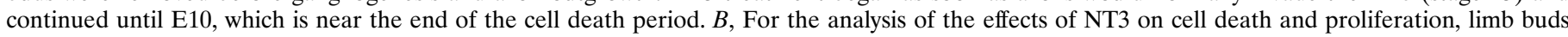

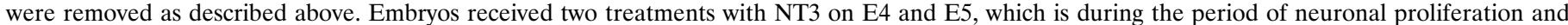

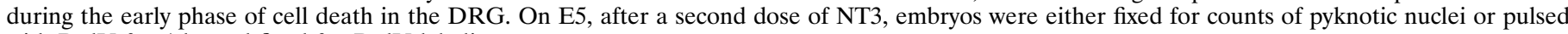
with BrdU for $4 \mathrm{hr}$ and fixed for BrdU labeling.

To begin to assess the role of neurotrophins in the specification of sensory neuron identity, we asked whether NT3 is sufficient to support the differentiation of muscle spindle afferents in the absence of limb muscle. The results indicate that even in the absence of limb muscle, NT3 can promote the survival of trkC+ sensory neurons and that these neurons make central projections typical of muscle spindle afferents. NT3 can therefore mimic the effects of limb muscle in the specification of this sensory phenotype.

\section{MATERIALS AND METHODS}

Production and characterization of trk antibodies. The production of antibodies to chick trkC and trkB have been detailed elsewhere (Lefcort et al., 1996; von Barthheld et al., 1996). A similar approach was used to 


\section{Transfection}

mock
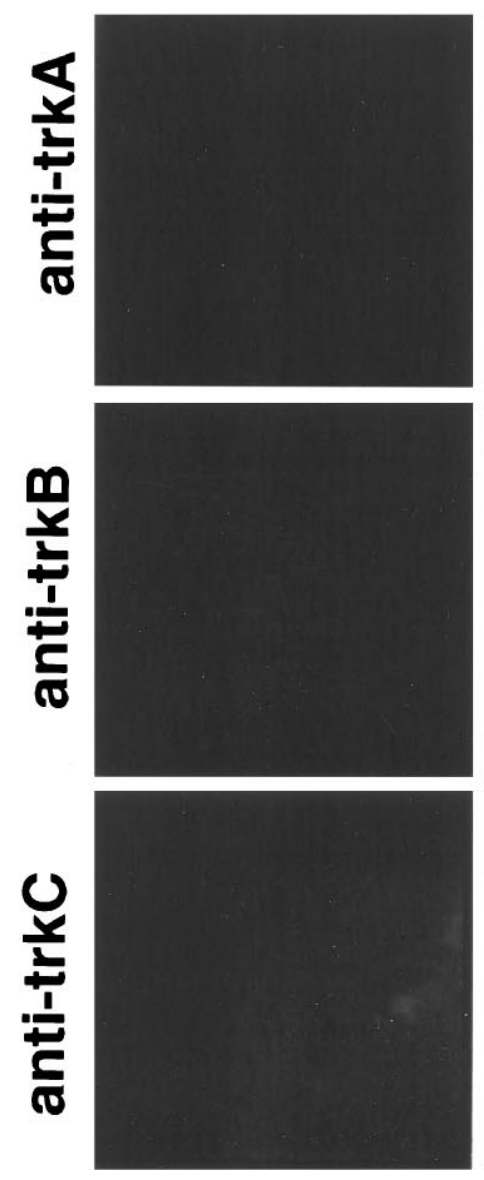

trkA
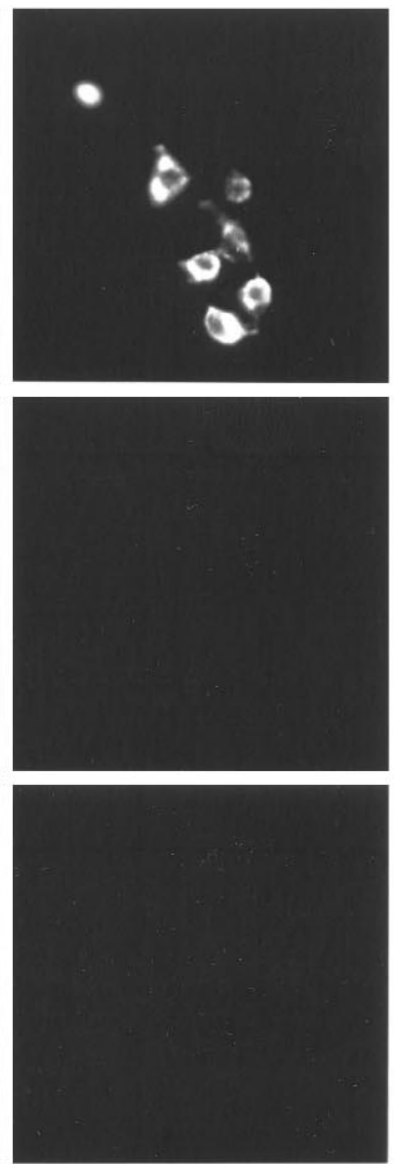

trkB
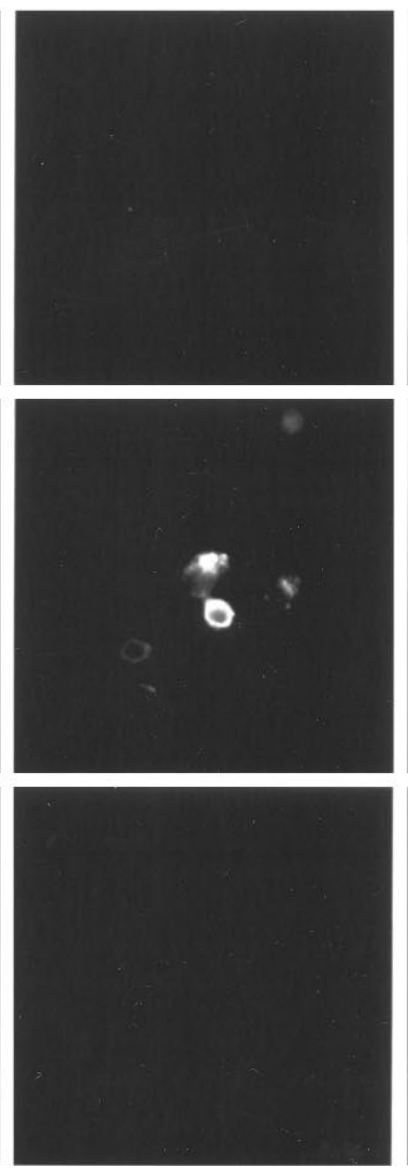

trkC
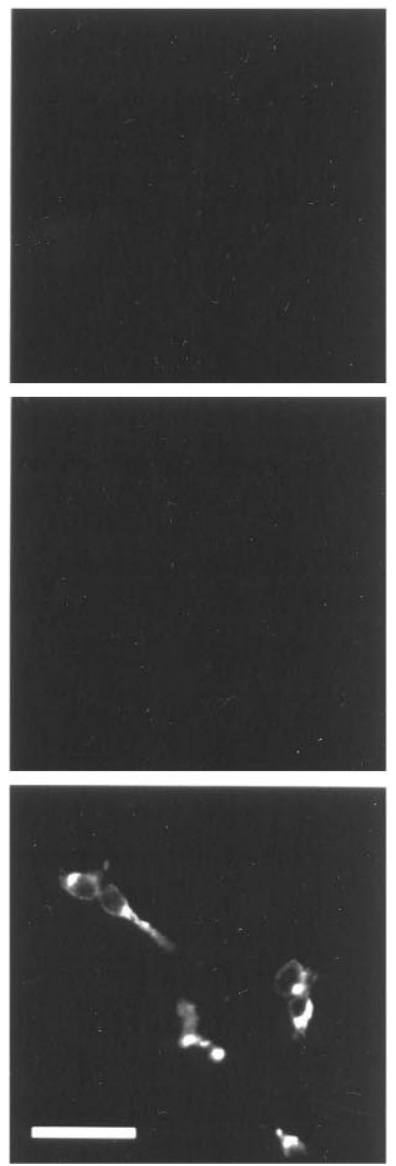

Figure 2. Specificity of antibodies to neurotrophin receptors. HEK 239 cells mock-transfected or transfected with chick cDNA encoding trkA, trkB, or trkC (columns). Transfected cells were immunolabeled with antibodies produced against the extracellular domains of chick trkA, trkB, and trkC (rows). Note that each antibody labels only cells transfected with the corresponding cDNA, and none of the antibodies cross-reacts detectably with cells expressing either of the other trk receptors.

produce antibodies to chick trkA. A full-length cDNA for chicken trkA was isolated from an E8 chick DRG library prepared in the plasmid vector CDM8 as previously described for chick trkC and trkB (Lefcort et al., 1996; von Barthheld et al., 1996). The portion of this cDNA encoding the entire extracellular domain of trkA was expressed in COS7 cells, and the resulting protein was purified and used to produce antibodies in rabbits as described for trkC (Lefcort et al., 1996). Because these antibodies are directed against the extracellular domains of the different trk receptors, they do not discriminate between full-length receptors and the different splice variants of trkB and trkC, which contain variable kinase domains (Garner and Large, 1994; Garner et al., 1996).

To characterize the specificity of these antibodies, human kidney 293 cells (HEK 293) were either mock-transfected or transiently transfected with chick cDNAs encoding full-length trkA, trkB, or trkC, as described previously (Lefcort et al., 1996). After $24 \mathrm{hr}$, the cells were fixed in $4 \%$ paraformaldehyde and reacted with either anti-trkA, anti-trkB, or antitrkC IgG, and binding was revealed with a fluorescent secondary antibody.

Embryonic surgery and neurotrophin treatments. Fertile eggs (SPAFAS) were windowed on the third day of incubation [embryonic day (E) 3, stage 17/18; Hamburger and Hamilton, 1951], and the right hindlimb bud was removed using flame-sharpened tungsten needles. The embryos were moistened with several drops of sterile saline containing $100 \mathrm{U} / \mathrm{ml}$ penicillin/streptomycin (Life Technologies, Grand Island, NY) and returned to the incubator for $\sim 48 \mathrm{hr}$. Beginning at stage 25 , when sensory and motor axons would normally begin to invade the limb (Tosney and
Landmesser, 1985), surviving embryos were treated once daily with 1, 5, or $10 \mu \mathrm{g}$ of human recombinant NT3 (Regeneron Pharmaceuticals, Tarrytown, NY) or cytochrome-C (control; Sigma, St. Louis, MO) by application to the chorioallantoic membrane. After five daily treatments, the surviving embryos were killed on E10 (stage 35/36), which is near the end of the period of normal cell death in the DRG (Carr and Simpson, 1978a). This time point is also well after the period when most sensory neurons switch from trkC expression to trkA expression (Lefcort et al., 1996; White et al., 1996; R. Oakley and F. Lefcort, unpublished observations). The timing of this experiment in relation to these developmental events is illustrated in Figure $1 A$.

The embryos were washed in PBS, decapitated, and eviscerated, and the thoracic and lumbosacral (LS) regions of the spinal cord were exposed via a ventral laminectomy. Limb-deleted embryos were classified as either complete or partial deletions, based on the pattern of nerves in the lumbosacral plexes on the deleted side. Complete deletion of limb musculature leads to a total disruption of normal nerve patterns in the plexes of the hindlimb, with the more anterior segments (LS1 and LS2) forming thoracic-like patterns and the more posterior segments projecting toward the tail (Tosney and Landmesser, 1984). Only embryos with complete hindlimb deletions were included for further analysis. These preparations were then processed for either immunohistochemistry or dorsal root labeling (see below).

Trk immunohistochemistry and cell counts. Partially dissected embryos were fixed for $18-24 \mathrm{hr}$ in $4 \%$ paraformaldehyde, washed in PBS, cryoprotected in $30 \%$ sucrose, embedded in a 2:1 mixture of $30 \%$ sucrose and 

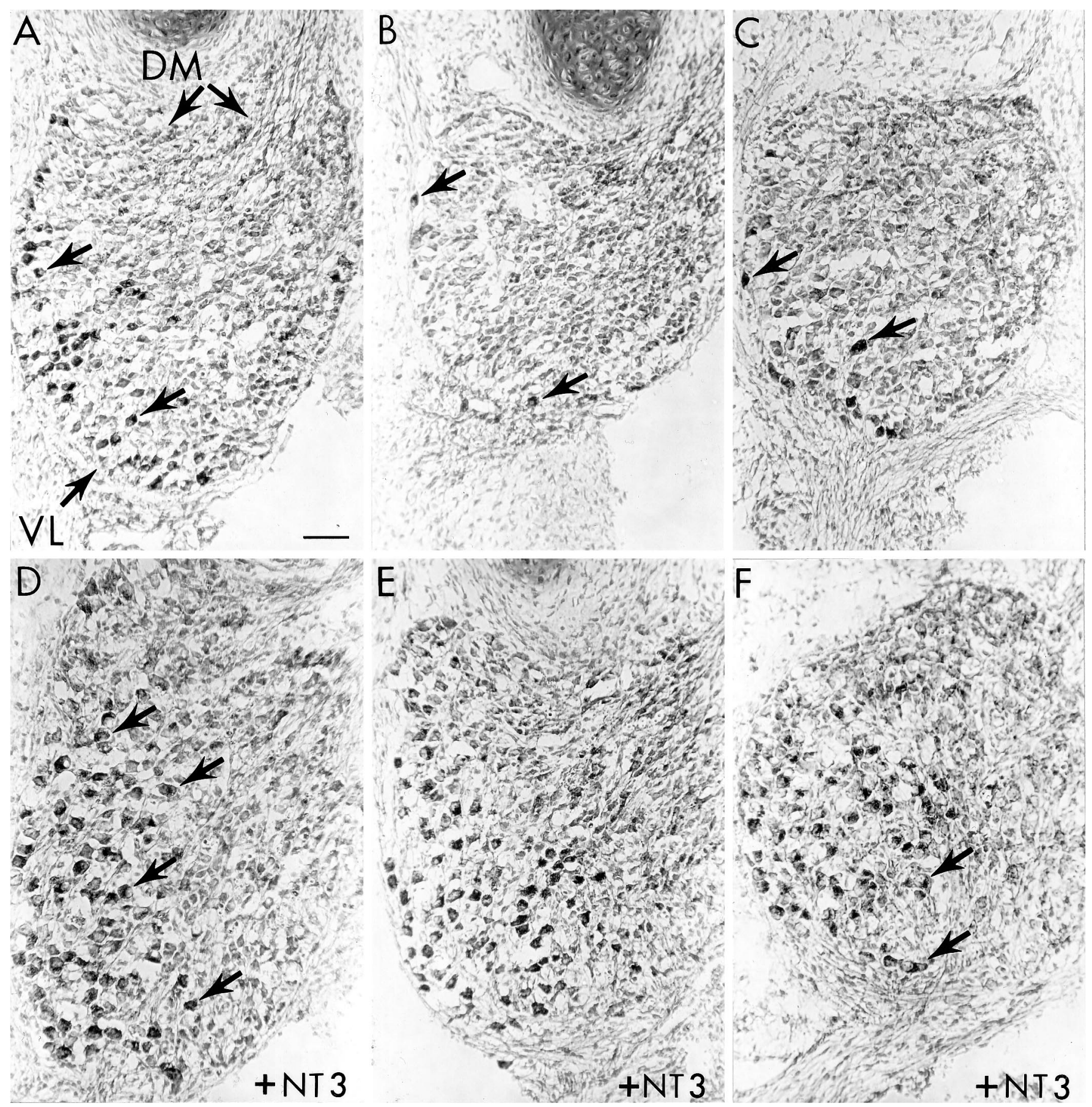

Figure 3. Effects of limb bud deletion and NT3 treatment on trkC+ sensory neurons. Transverse sections of E10 DRG from control $(A-C)$ and NT3-treated $(D-F)$ embryos are stained for trkC. $A$, In normal lumbar DRG of control embryos, trkC + neurons (arrows) were mainly confined to the ventrolateral $(V L)$ region of each ganglion. $B$, In lumbar DRG on the limb-deleted side, few trkC+ neurons (arrows) survived, and the VL aspect of the DRG was reduced (compare with $A$ ). $C$, In thoracic DRG of control embryos, few trkC+ neurons (arrows) were normally detected. As in lumbar segments, these neurons were localized primarily to the VL region. $D$, In normal lumbar DRG, NT3 treatment $(10 \mu \mathrm{g} / \mathrm{d})$ increased the number of trkC + neurons (arrows) within the VL region (compare with $A$ ). $E$, In lumbar DRG on the limb-deleted side, NT3 treatment rescued the trkC+ population and maintained the normal size of the VL region (compare with $A$ and $B$ ). $F$, In thoracic DRG, NT3 treatment increased the trkC+ population (arrows) and expanded the VL region of the DRG. In each panel, the orientation is the same: dorsal is up and lateral is to the left. VL indicates the ventrolateral region of the ganglion, and DM indicates the dorsomedial region. In this figure and in Figures 4 and 5, the lumbar ganglia shown are from LS3 and the thoracic ganglia shown are from T5 or T6. The ganglia shown are the same ganglia that were used for cell counts (Fig. 6). Scale bar, $50 \mu \mathrm{m}$.

OCT (Miles Scientific, Elkhart, IN), and frozen on dry ice. Serial, $10 \mu \mathrm{m}$ frozen sections were cut on a Reichert-Jung cryostat and collected on Super-Frost Plus slides (Fisher, Pittsburgh, PA). Immunostaining with antibodies to all three trk receptors was preformed as described previously for trkC (Lefcort et al., 1996). After they were immunostained, the sections were lightly counterstained in cresyl violet, dehydrated, and coverslipped in DPX (Aldrich Chemical, Milwaukee, WI). Immunoreactive neurons within the DRG that had a distinct nucleus and at least one nucleolus were counted in every fourth section at $400 \times$ using phasecontrast optics. No correction factors were applied to the raw counts 
Table 1. Counts of pyknotic nuclei in DRG at E 5.5

\begin{tabular}{lcc} 
& Control & $+\mathrm{NT} 3$ \\
\hline Normal lumbar & $44 \pm 9.0$ & $7.5 \pm 2.1^{*}$ \\
Deleted lumbar & $354 \pm 44.5$ & $78.3 \pm 12.6^{* *}$ \\
Normal thoracic & $229 \pm 21.1$ & $60.8 \pm 12.6^{* *}$
\end{tabular}

NT3 treatment rescues DRG neurons from cell death due to target deprivation Limb bud deletion results in excessive cell death on the deleted side, which is largely blocked by exogenous NT3. Treatment with NT3 also significantly reduced cell death in DRG with normal targets (i.e., contralateral lumbar and thoracic). Values are the mean number of pyknotic nuclei per DRG \pm SEM. $p$ values are from comparisons of control and respective NT3-treated means using a one-tailed Student's $t$ test. Data are from five to six embryos for each group. ${ }^{*} p<0.0025 ;{ }^{*} p<0.0005$.

Table 2. Counts of BrdU-labeled cells in DRG at E 5.5

\begin{tabular}{lll} 
& Control & + NT3 \\
\hline Normal lumbar & $256 \pm 49$ & $242 \pm 46$ \\
Deleted lumbar & $224 \pm 43$ & $274 \pm 52$
\end{tabular}

Neither limb bud deletion nor NT3 treatment had a significant effect on the proliferation of DRG precursers as assessed using a $4 \mathrm{hr}$ exposure to BrdU on E5. BrdU-labeled cells were counted in every other section through the L3 DRG. Values are the mean $( \pm$ SEM) number of labeled cells times 2 per 1000 healthy DRG cells Means were compared using the Student's $t$ test. Data are from four embryos for each group.

(Clarke and Oppenheim, 1995). Neurons were counted bilaterally in LS3 and unilaterally in a midthoracic DRG from each embryo. For trkB+ cells, the cells were classified further as to their location in the ganglion [dorsomedial (DM) or ventrolateral (VL); see Fig. 5].

Labeling of sensory projections. After ventral laminectomy, all of the lumbosacral and thoracic dorsal roots on both sides were pressureinjected with 1,1'-dioctadecyl-3,3,3',3'-tetramethylindocarbocyanine perchlorate (DiI), $5 \mathrm{mg} / \mathrm{ml}$ in $90 \%$ ethanol, $10 \%$ dimethyl sulfoxide (Molecular Probes, Eugene, OR) (Honig and Hume, 1986) using broken micropipettes. In some embryos, only the dorsal roots of thoracic level ganglia were labeled. Spinal cords with attached DRG were then fixed in $4 \%$ paraformaldehyde in PBS for at least $48 \mathrm{hr}$ at room temperature. Thoracic and lumbar regions of the cord were embedded in $19 \%$ gelatin and sectioned at $40-60 \mu \mathrm{m}$ using a vibrating microtome. The sections were mounted in Gelmount (Biomedia, Foster City, CA) and photographed immediately.

Assessment of cell death and proliferation. To determine the effect of limb bud deletion and NT3 treatment on cell birth and death in the DRG, we analyzed two separate sets of embryos at stage 27 (E5.5) after two doses of NT3 (10 $\mu \mathrm{g}$ each). These embryos therefore were exposed to NT3 during a period when active cell proliferation in the DRG overlaps with the earliest phase of target interaction and cell death. The timing of these experiments in relation to these developmental events is illustrated in Figure $1 B$.

For the analysis of cell death, embryos were killed $\sim 4 \mathrm{hr}$ after the second dose of NT3 or cytochrome-C (control), fixed in Bouin's solution, dehydrated, embedded in paraffin, and sectioned at $6 \mu \mathrm{m}$. After staining with hematoxylin and eosin, pyknotic nuclei were counted in every fifth section through lumbar (LS3) and thoracic (T6) DRG as described previously (Clarke and Oppenheim, 1995).

For the analysis of cell proliferation, embryos received $10 \mu \mathrm{g}$ of bromodeoxyuridine (BrdU) (Sigma, St. Louis, MO) with the second dose of NT3. Approximately $4 \mathrm{hr}$ later, the embryos were killed, fixed in Carnoy's solution, dehydrated, embedded in paraffin, and serially sectioned at $6 \mu \mathrm{m}$. After rehydration, sections were incubated in $1 \mathrm{~N} \mathrm{HCl}$ at $37^{\circ} \mathrm{C}$ for $30 \mathrm{~min}$, neutralized in $0.05 \mathrm{M}$ borate buffer, $\mathrm{pH} 8.5$, and washed in PBS. Sections were then incubated for $60 \mathrm{~min}$ in anti-BrdU (Sigma) diluted 1:20 in blocking buffer (PBS with $0.1 \%$ Triton X-100 and 1\% normal horse serum), washed three times in PBS, and incubated for 60 min in a biotinylated secondary antibody $(5 \mu \mathrm{l} / \mathrm{ml}$ in blocking buffer). After they were washed three times in PBS, the sections were reacted with the $\mathrm{ABC}$ reagent (Vector, Burlingame, $\mathrm{CA}$ ), washed three times in PBS, developed in diaminobenzidine with nickel intensification, dehydrated, and mounted. BrdU-labeled cells with a distinct nuclear membrane were counted in every other section through the LS3 DRG. This procedure labels $\sim 10 \%$ of all DRG cells at this stage of development (see Table 2). We therefore estimate that this procedure labels at least $20 \%$ of the dividing cells of the DRG, because even much longer exposures to BrdU (12 hr) label only $50 \%$ of DRG cells at earlier stages (E4), when fewer neurons have differentiated (F. Lefcort, unpublished observations).

\section{RESULTS}

\section{Antibody specificity}

To determine whether the antibodies produced against individual trk receptors specifically recognized a single type of trk receptor, HEK 293 cells were transfected with cDNA encoding a single trk receptor and reacted with each trk antibody (Fig. 2). Each antibody was found to react only with cells transfected with the corresponding cDNA and not with cells expressing other trk receptor types. These results thus demonstrate the utility of this set of antibodies for the selective immunodetection of the different trk receptors. Moreover, these antibodies selectively labeled distinct populations of neurons in E10 chick DRG (see below), which further confirms their specificity.

\section{NT3 prevents the death of trkC+ neurons deprived of limb targets}

In control embryos, limb bud deletion led to a reduction in the number of trkC+ sensory neurons (Fig. 3; see Fig. 6A). In lumbar DRG contralateral to the deletion (i.e., with normal targets), trkC + neuronal somata were large in diameter and primarily localized to the VL region of each ganglion (Fig. $3 A$ ). This distribution is typical of trkC + neurons in normal lumbar and brachial DRG (Oakley et al., 1995; Lefcort et al., 1996). Limb bud removal resulted in a dramatic loss of trkC+ neurons in lumbar DRG ipsilateral to the deletion (Fig. $3 B$ ). Cell counts revealed that only $\sim 10 \%$ of the normal complement of trkC + neurons survived in the absence of developing limb tissues (Fig. 6A). The deletion also resulted in an obvious reduction in the size of the VL region in the ipsilateral DRG (compare Fig. 3, $A$ and $B$ ). Thus, the trkC + population of the $\mathrm{VL}$ region is especially sensitive to the absence of limb targets during the cell death period.

A similar loss of VL neurons occurs during the cell death period in thoracic DRG, presumably because these neurons do not find limb targets (Hamburger and Levi-Montalcini, 1949). We therefore examined normal thoracic DRG in segments unaffected by the surgery. As expected, thoracic DRG normally contained fewer trkC + neurons at E10 than unoperated lumbar DRG did (Fig. $3 C)$. Cell counts indicated that the trkC+ population in thoracic DRG is only $\sim 20 \%$ of that found in unoperated lumbar DRG (see Fig. 6A) and was thus numerically similar to the population of trkC + neurons that remains in ipsilateral DRG after limb bud deletion.

NT3 treatment led to a significant increase in the number of trkC + neurons in all DRG examined. In all cases, these neurons were localized mainly to the VL region of the DRG. In lumbar DRG with normal targets (contralateral), exogenous NT3 at a dose of $10 \mu \mathrm{g} / \mathrm{d}$ nearly doubled the population of $\operatorname{trkC}+$ neurons (Fig. 3D; see Fig. 6A). In lumbar DRG deprived of limb targets (ipsilateral), NT3 maintained an approximately normal number of trkC+ neurons (Fig. 3E; see Fig. 6A), despite the absence of these targets. This treatment also restored the normal morphology of the VL region ipsilateral to the deletion (compare Fig. 3, $B$ and $E)$. In thoracic DRG, this dose resulted in a fourfold increase in the number of trkC+ neurons (see Fig. $6 A$ ) and thus produced a trkC + population equivalent to that of a normal lumbar DRG. This treatment also led to an obvious expansion of the VL region in thoracic DRG (Fig. $3 F$ ). 

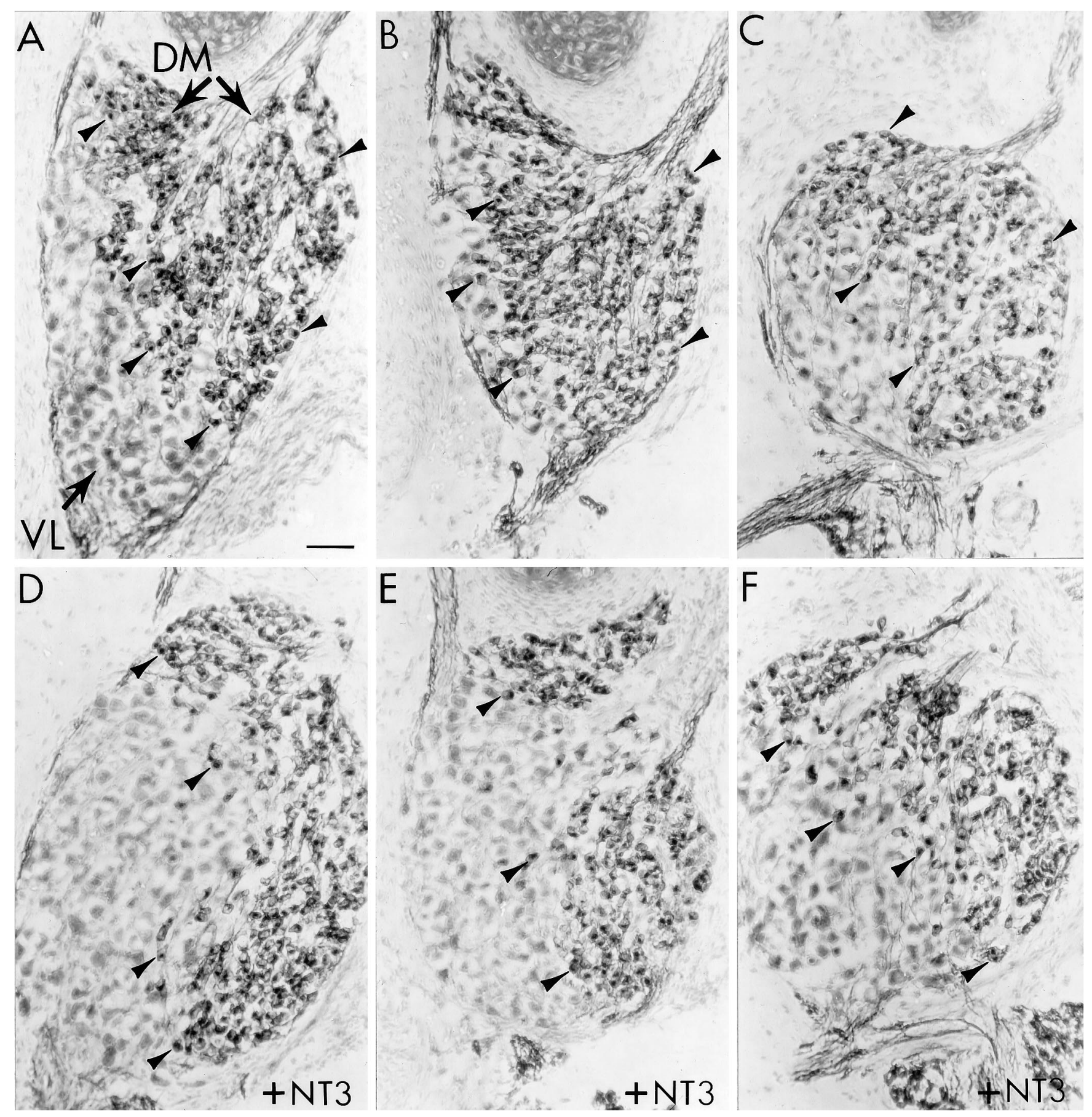

Figure 4. TrkA + neurons are less sensitive to limb bud deletion, and their survival is not altered by NT3. Transverse sections of E10 DRG from control $(A-C)$ and NT3-treated $(D-F)$ embryos stained for trkA. $A$, In normal lumbar DRG of control embryos, trkA+ neurons (arrowheads) were confined mainly to the dorsomedial $(D M)$ region of each ganglion. $B$, In lumbar DRG on the limb-deleted side, many trkA+ neurons (arrowheads) survived in control embryos despite the obvious reduction in the size of the ventrolateral $(V L)$ region (compare with $A$ ). $C$, In thoracic DRG, trkA+ neurons (arrowheads) were also localized to the DM region. $D$, In normal lumbar DRG, NT3 treatment (10 $\mu \mathrm{g} / \mathrm{d})$ had no obvious effect on trkA+ neurons (arrowheads), but did cause an expansion of the trkA-negative VL region (compare $A$ and Fig. $3 D$ ). $E$, In lumbar DRG on the limb-deleted side, NT3 treatment also expanded the trkA-negative VL region without altering the survival of trkA+ neurons (arrowheads; also see Fig. 6). F, NT3 had a similar effect in thoracic ganglia. In each panel, dorsal is up and lateral is to the left. Scale bar, $50 \mu \mathrm{m}$.

The effect of NT3 on trkC + neurons was dose-dependent. The lowest dose used $(1 \mu \mathrm{g} / \mathrm{d})$ was ineffective, and an intermediate dose $(5 \mu \mathrm{g} / \mathrm{d})$ only partially restored the trkC + population (data not shown). Moreover, the highest dose tested $(10 \mu \mathrm{g} / \mathrm{d})$ was apparently subsaturating. In embryos treated with this dose, lumbar DRG supplying normal targets (contralateral) contained about twice the number of trkC+ neurons as did lumbar DRG ipsilateral to the deletion (see Fig. $6 A$ ). This suggests that on the side with the intact limb, the exogenous NT3 combined with endogenous sources to support the survival of more trkC+ neurons than could be supported by exogenous NT3 alone.

To determine whether NT3 increased the trkC + population by 

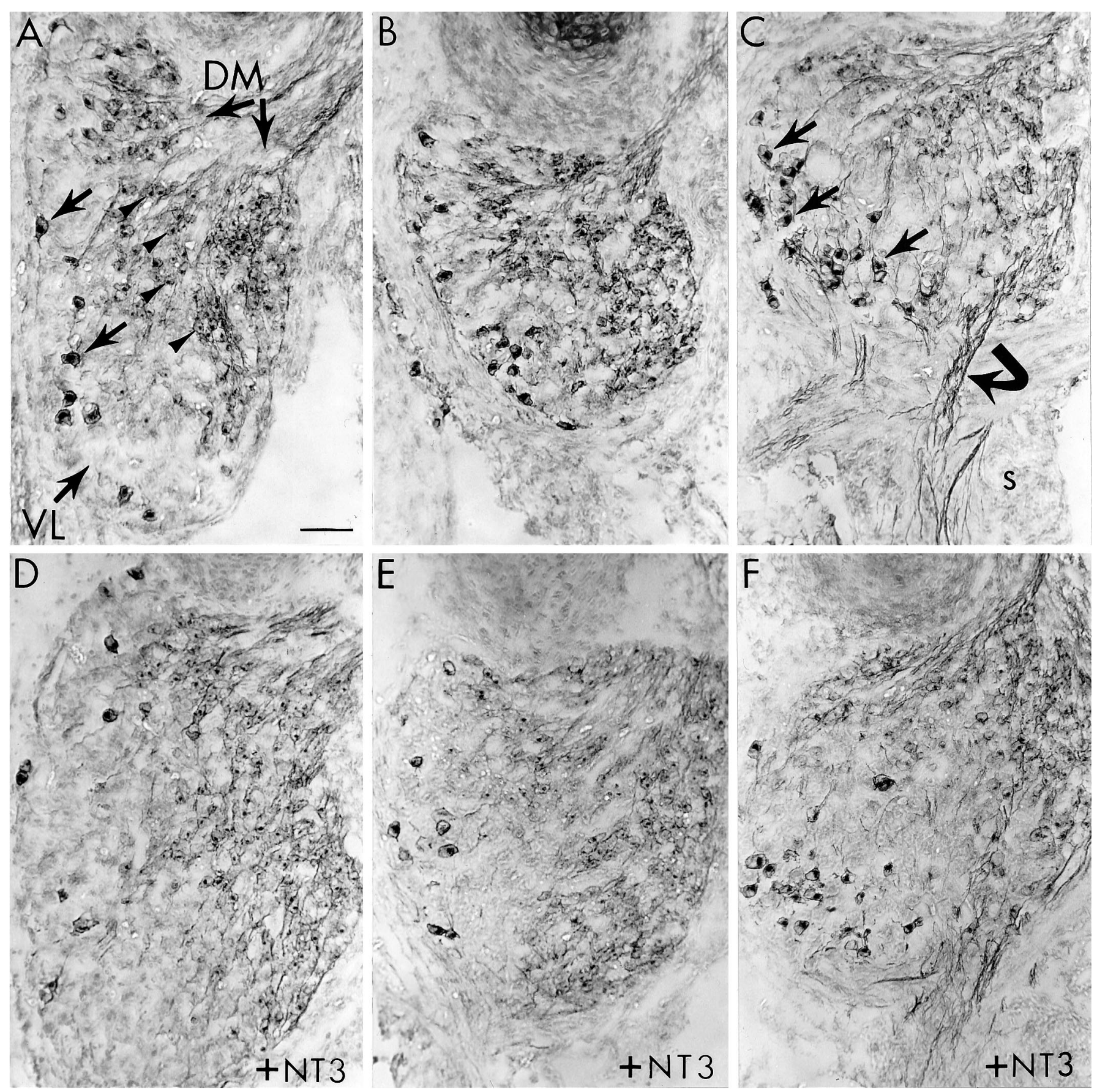

Figure 5. TrkB + neurons are insensitive to both limb bud deletion and NT3 treatment. Transverse sections of E10 DRG from control $(A-C)$ and NT3-treated $(D-F)$ embryos stained for trkB. $A$, In the normal lumbar DRG of control embryos, two distinct populations of trkB+ neurons can be identified: large diameter ventrolateral $(V L)$ neurons (arrows) and smaller dorsomedial (DM) neurons (arrowheads). B, In lumbar DRG on the limb-deleted side, both classes of trkB + neurons survived in control embryos. $C$, Thoracic DRG in control embryos contained more trkB $+\mathrm{VL}$ neurons (arrows) than did lumbar ganglia. In thoracic ganglia, trkB + fibers (curved arrow) can be seen extending into the sympathetic chain $(s)$. $D$, In normal lumbar DRG, NT3 treatment (10 $\mu \mathrm{g} / \mathrm{d})$ had no obvious effect on the number of trkB neurons in either the VL or DM regions, but NT3 did cause an expansion of the trkB-negative portion of the VL region (compare $A$ ). $E$, In lumbar DRG on the deleted side, NT3 treatment also expanded the trkB-negative VL region without altering the survival of either population of trkB+ neurons. $F$, NT3 had a similar effect in thoracic DRG. In all panels, dorsal is up and lateral is to the left. Scale bar, $50 \mu \mathrm{m}$.

preventing cell death, we analyzed a separate set of embryos at stage 27 (E5.5; Fig. $1 B)$. This is when cell death in the VL region of the DRG is maximal both during normal development and in response to limb bud deletion (Carr and Simpson, 1978a,b; Hamburger et al., 1981; Hamburger and Yip, 1984). As expected, limb bud deletion caused a dramatic increase in the number of pyk- notic nuclei in lumbar DRG on the deleted side (Table 1). This increase in cell death was largely blocked by exogenous NT3, leading to a significant decrease in the number of pyknotic nuclei on the deleted side. In addition, NT3 treatment resulted in a significant reduction in cell death in lumbar DRG with normal limb targets (contralateral). NT3 also reduced cell death in tho- 


\section{A. trkC-positive sensory neurons}

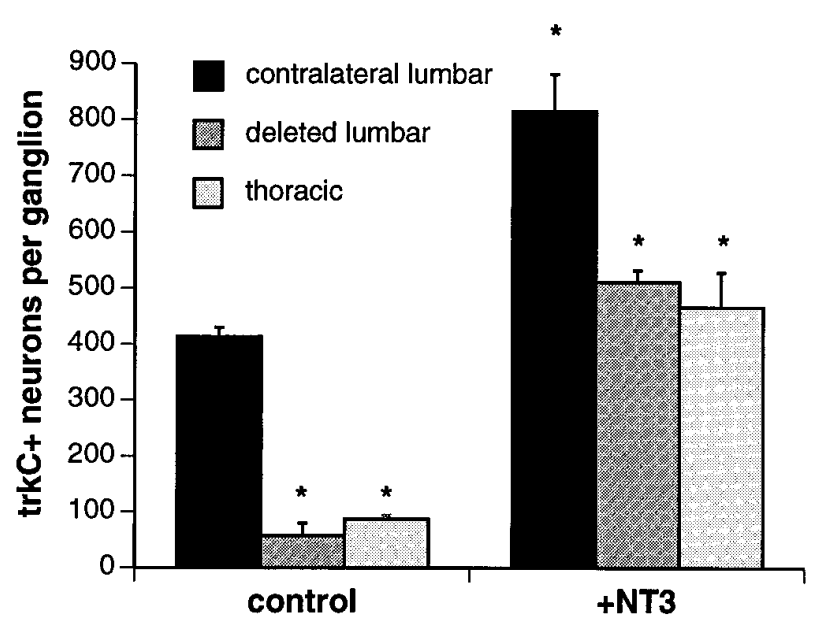

\section{B. trkA-positive sensory neurons}

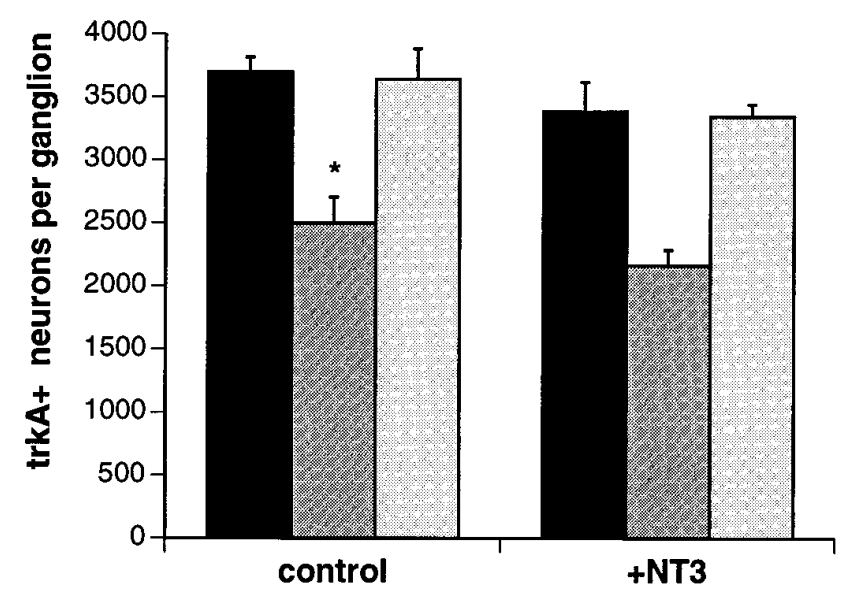

\section{C. trkB-positive sensory neurons}

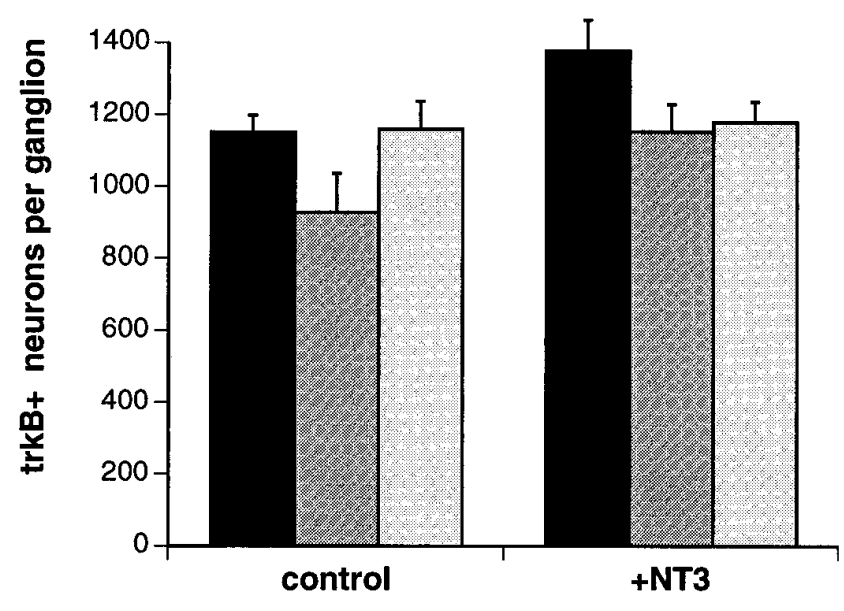

Figure 6. Quantitative analysis of sensory neuron survival on E10 after limb bud deletion and treatment with NT3 at $10 \mu \mathrm{g} / \mathrm{d} . A$, Most trkC+ neurons were eliminated in lumbar DRG on the deleted side; the number of trkC + neurons remaining was approximately the same as in normal thoracic DRG. NT3 treatment resulted in an approximately normal number of trkC + neurons in lumbar DRG on the deleted side and doubled racic DRG to approximately the level seen in normal lumbar DRG, suggesting that the exogenous NT3 rescues cells that normally die because of a lack of access to limb targets. These results indicate that one of the ways NT3 increased the trkC+ population was by rescuing these neurons from cell death.

NT3 has also been implicated in the control of cell proliferation in peripheral ganglia (Kalcheim et al., 1992, DiCicco-Bloom et al., 1993; Elshamy and Ernfors, 1996; Ockel et al., 1996; but see Fariñas et al., 1996). To determine whether NT3 altered the proliferation of sensory precursors, we examined BrdU incorporation at stage $27($ E5.5; Fig. $1 B)$. This is on the second day of the NT3 treatment and is during a period of active neurogenesis within the DRG when many VL neurons are generated (Carr and Simpson, 1978a). Neither limb bud deletion nor NT3 treatment significantly altered the number of BrdU-labeled cells in lumbar DRG (Table 2). These results suggest that changes in neuronal proliferation cannot account for the increase in the trkC+ population. Our results are somewhat at odds with those of Ockel et al. (1996), who found that NT3 treatment beginning on E3 leads to a decrease in proliferation on E4.5, as assessed by PCNA labeling. Although we did not detect any decrease in proliferation after NT3 treatment, this may be attributable to differences in the timing of the experiment (Fig. $1 B$ ) or to differences in the method used for the analysis of proliferation.

\section{Other populations of sensory neurons are not rescued by NT3}

Limb bud deletion also resulted in a significant decrease in the survival of trkA + DRG neurons. In both normal lumbar and thoracic DRG, these neurons were primarily localized to the DM region of each ganglion (Fig. 4A,C). In lumbar ganglia that lacked limb targets (ipsilateral), the deletion resulted in an obvious reduction of the $\mathrm{VL}$ region, which is primarily trkA-negative (compare Fig. 4, $A$ and $B$ ). In addition, cell counts revealed a significant loss of $\sim 35 \%$ of the trkA+ population in lumbar DRG in the absence of limb targets. This loss of trkA+ neurons ipsilateral to the deletion was not reversed by treatment with NT3 (see Fig. 6B). NT3 also had no detectable effect on the trkA+ population in either contralateral lumbar or thoracic DRG (see Fig. 6B). Although NT3 did not alter the survival of trkA+ neurons, it did cause an obvious expansion of the trkA-negative VL region in all ganglia examined (Fig. $4 D-F$ ).

The absence of limb targets had only marginal effects on trkB + sensory neurons. At E10, two distinct populations of trkB + DRG neurons could be distinguished based on size and position: large-diameter VL neurons and smaller DM neurons. Both classes of trkB + neurons were detected in lumbar and thoracic DRG (Fig. 5A,C), with about twice as many large VL

\footnotetext{
this population on the normal side. NT3 treatment also increased the trkC + population in thoracic DRG to approximately the level in normal lumbar DRG. $B$, Limb bud deletion significantly reduced the trkA+ population by $\sim 40 \%$ in lumbar DRG on the deleted side. This population was not increased significantly by NT3 treatment. $C$, Limb bud deletion had only marginal effects on trkB + neurons, which were not statistically significant. The numbers of trkB + neurons in lumbar and thoracic DRG were not significantly altered by NT3 treatment. Values are mean \pm SEM (5 embryos for each group); lumbar counts are all from LS3; asterisks indicate significant differences. In control embryos, means of cell counts in thoracic and limb-deleted lumbar DRG were compared statistically with those of normal lumbar DRG. In NT3-treated embryos, means were compared with the respective means for control DRG. All comparisons were made using a two-tailed $t$ test.
} 

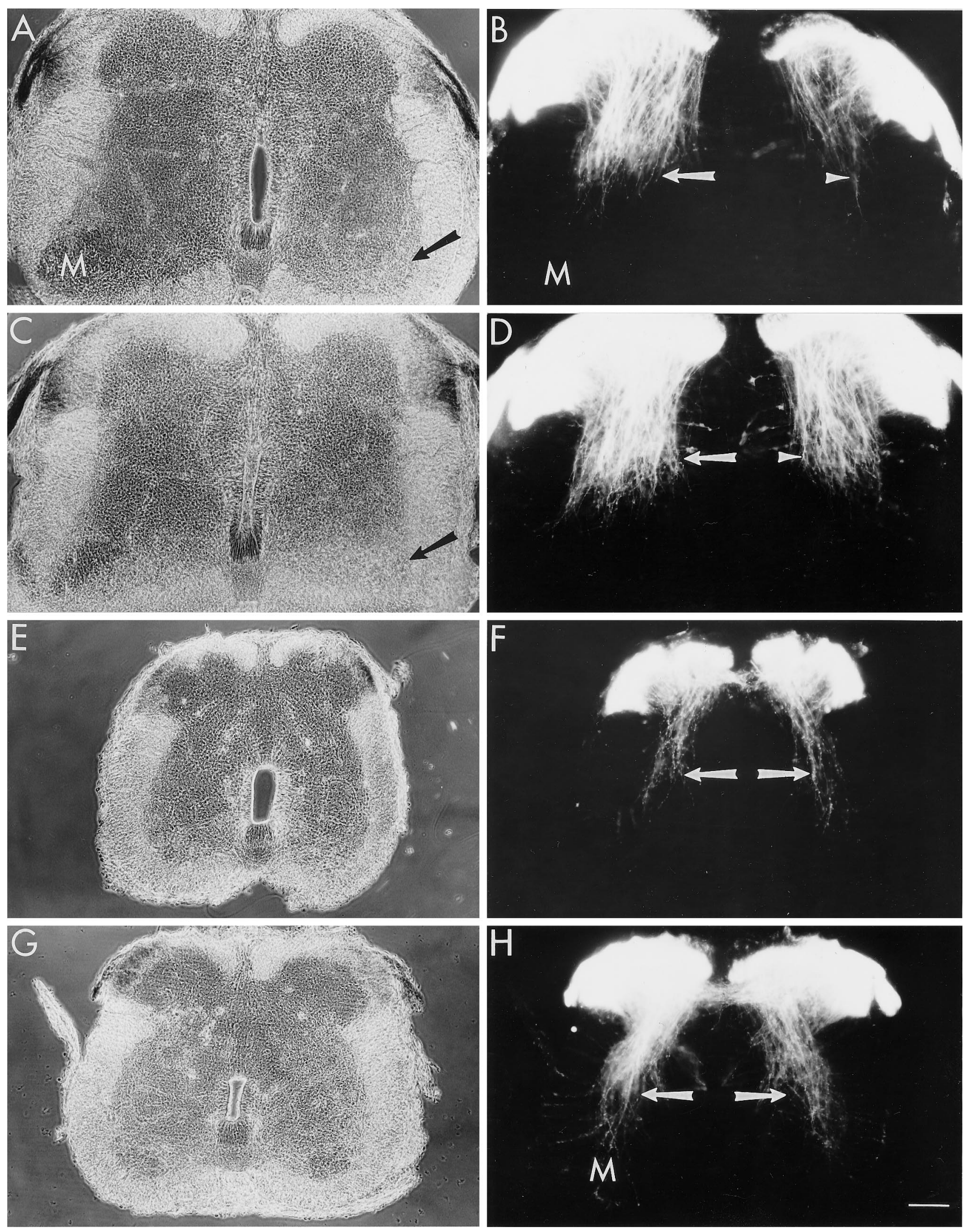

Figure 7. NT3 increases the number of muscle spindle afferent collaterals in lumbar and thoracic segments. Transverse sections of E10 lumbar $(A-D)$ and thoracic $(E-H)$ spinal cord from control and NT3-treated $(10 \mu \mathrm{g} / \mathrm{d})$ embryos after DiI labeling of dorsal roots. $A$, Phase-contrast image of lumbar cord from a control embryo. The lateral motor column $(M)$ is reduced ipsilateral (right, arrow) to the limb bud deletion. $B$, Fluorescence image of sensory fibers as revealed by DiI labeling. Contralateral to the deletion, the collateral fibers of muscle spindle afferents (Ia fibers, arrow) extend toward the motor column $(M)$. This population of fibers was markedly reduced ipsilateral to the deletion (arrowhead). Figure legend continues. 

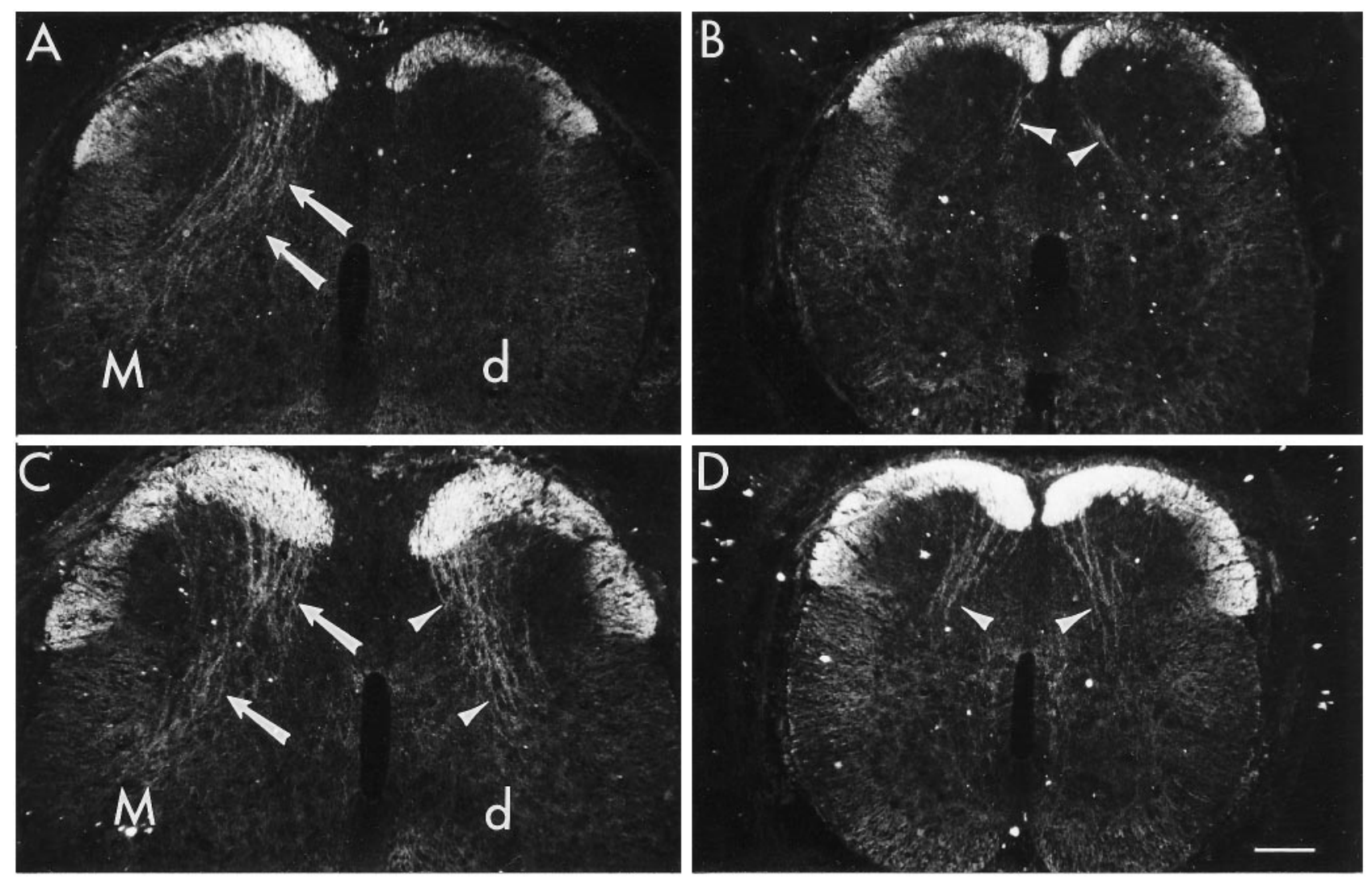

Figure 8. TrkC localization to the collateral fibers of muscle spindle afferents. Transverse sections of E10 lumbar $(A, C)$ and thoracic $(B, D)$ spinal cord from control and NT3-treated embryos after immunolabeling with antibodies to trkC. $A$, In control embryos, few trkC + collateral fibers develop in the lumbar spinal cord on the deleted side $(d)$. Contralateral to the deletion, trkC + collaterals (arrows) of muscle spindle afferents project toward motoneurons $(M) . B$, In control embryos, few trkC+ collaterals (arrowheads) are present in thoracic segments of the spinal cord. $C$, NT3 treatment restores the trkC+ collaterals (arrowheads) on the deleted side $(d)$ of the lumbar spinal cord. NT3 treatment also increased the density of trkC+ fibers (arrows) that project toward motoneurons $(M)$ on the contralateral side. $D$, NT3 treatment also resulted in an increase in the number of trkC+ collaterals (arrowheads) in thoracic segments. All panels are dark-field images of HRP labeling. Dorsal is $u p$ in all panels. Scale bar, $100 \mu \mathrm{m}$.

neurons in thoracic ganglia as in lumbar ganglia (data not shown). At least some of the small-diameter trkB+ neurons are likely to be visceral afferents, because trkB + projections from DM neurons to the sympathetic chain were often detected (Fig. $5 C)$. Limb bud deletion had no obvious effect on either population of trkB + neurons (Fig. $5 B$ ). Moreover, there was no significant change in the trkB + population in lumbar DRG on the deleted side, regardless of whether the two populations were considered together (Fig. 6C) or separately (data not shown). Finally, neither population was significantly affected by NT3. Although treatment with NT3 had no significant effect on the survival of trkB + neurons in any of the ganglia examined, there was a trend toward more trkB + neurons on the deleted side $(p=0.13)$ and in DRG with normal limb targets $(p=$ 0.06) after NT3 treatment (Fig. 6C). NT3 also consistently caused an expansion of the trkB-negative portion of the $\mathrm{VL}$ region in all ganglia examined (Fig. $5 D-F$ ).

\section{NT3 rescues muscle spindle afferents in the absence of limb targets}

To determine whether the neurons rescued by NT3 made spinal projections appropriate for muscle spindle afferents, we examined the collateral projections of sensory neurons within the spinal cord by labeling dorsal roots with DiI. Collaterals of spindle afferents (Ia fibers) have a characteristic projection pattern, in that they are the only sensory neurons that project ventrally to synapse with motoneurons in the lateral motor column. In control embryos $(n=4)$, limb bud deletion led to a marked loss of Ia fibers on the side of the deletion (Fig. $7 B$ ). This result is consistent with the major loss of large trkC + sensory neurons on the deleted side. There was also an obvious reduction in the lateral motor column ipsilateral to the deletion, attributable to the death of many motoneurons that normally supply the deleted limb muscles (Fig. $7 A)$. NT3 treatment $(10 \mu \mathrm{g} / \mathrm{d} ; n=4)$ led to a restoration of an apparently normal set of Ia collaterals on the deleted side.

$C$, Lumbar spinal cord from an NT3-treated embryo. The lateral motor column remains reduced ipsilateral to the deletion (arrow). $D$, NT3 treatment restored a nearly normal population of Ia fibers ipsilateral to the deletion (arrowhead) and increased this population of fibers on the contralateral side (arrow). E, $F$, Thoracic spinal cord from a control embryo. In control cords, fewer Ia fibers (arrows) are present in thoracic segments than in normal lumbar segments (compare $B$, left). $G, H$, Thoracic spinal cord from an NT3-treated embryo. NT3 increased the number of Ia fibers (arrows) that project toward motoneurons $(M)$ in thoracic segments. Dorsal is up in all panels. Scale bar, $100 \mu \mathrm{m}$. 
These fibers projected toward the ventral horn, similar to the Ia fibers on the normal (contralateral) side of the spinal cord (Fig. $7 D)$. NT3 also caused a marked increase in the density of the Ia projection on the contralateral side (Fig. 7D), consistent with the increase in the number of trkC + neurons in normal lumbar DRG (Fig. 6A); however, NT3 failed to restore the normal morphology of the lateral motor column, which remained reduced (Fig. 7C). This result suggests that NT3 does not rescue motoneurons from cell death due to target deprivation in vivo, a conclusion that is also supported by counts of motoneurons in these embryos ( $\mathrm{J}$. Calderó, D. Prevette, R. Oakley, and R. Oppenheim, unpublished observations).

The effect of NT3 on the Ia fiber projection was dosedependent, with the lowest dose $(1 \mu \mathrm{g} / \mathrm{d} ; n=2)$ being ineffective and an intermediate dose ( $5 \mu \mathrm{g} / \mathrm{day} ; n=4)$ only partially restoring this population of fibers (data not shown). Because these central projections develop well after cell death begins (stage 32-34), these results demonstrate that NT3 led to both the survival and the differentiation of muscle spindle afferents in DRG that lacked peripheral limb targets.

The effect of NT3 on the Ia projection to motoneurons was also obvious in the thoracic spinal cord. In control embryos, there are fewer collateral fibers projecting to motoneurons in thoracic segments than in lumbar segments (Fig. 7E,F), in agreement with the smaller number of trkC + neurons in thoracic DRG. As in lumbar segments, NT3 treatment led to a robust increase in the number of Ia collaterals projecting to motoneurons in thoracic segments (Fig. 7G,H). The increased density of spindle afferent fibers in the thoracic spinal cord was attributable to an increased projection from thoracic level DRG, because it was also detected even when only thoracic dorsal roots were labeled (Fig. $7 F, H$; $n=4)$.

To be certain that the sensory projections restored by NT3 originated from trkC + neurons, we also examined spinal projections using antibodies to trkC (Fig. 8). In control embryos, antibodies to trkC intensely label the collateral fibers of muscle spindle afferents within the lumbar spinal cord contralateral to the deletion. As expected, limb bud deletion virtually eliminated these trkC + fibers on the deleted side (Fig. $8 A$ ). Similarly, relatively few trkC + collaterals were detected in thoracic segments from control embryos (Fig. $8 \mathrm{~B}$ ), in agreement with the relative paucity of trkC + neurons in thoracic DRG. In lumbar segments, NT3 treatment restored an apparently normal population of trkC + collateral fibers on the deleted side and resulted in an increase in the density of these fibers on the contralateral side (Fig. $8 C$ ). In addition, NT3 led to a marked increase in the density of trkC+ collaterals in thoracic segments (Fig. 8D). These results indicate that NT3 promoted the survival and differentiation of trkC + muscle spindle afferents in both thoracic and lumbar DRG in the presence and absence of normal peripheral targets.

\section{DISCUSSION}

Our results show that NT3 can promote the development of sensory neurons that exhibit two important hallmarks of the muscle spindle afferent phenotype: trkC expression and collateral projections to the ventral spinal cord. NT3 is therefore sufficient to promote the differentiation of muscle spindle afferents, even in the absence of other limb-derived signals. Because these neurons also require NT3 to survive the cell death period (Oakley et al., 1995), we conclude that NT3 is both necessary and sufficient for the development of muscle spindle afferents. These results therefore suggest an important role for NT3 in the specification of this sensory phenotype.

\section{NT3 prevents the death of muscle spindle afferents}

Early deletion of the avian limb bud prevents the development of limb tissues and results in an increase in the death of both motor and sensory neurons. In the absence of limb targets, more neurons than usual die in both populations, during the period when targets are normally being innervated (Hamburger and Levi-Montalcini, 1949; Hamburger, 1958, 1975; Carr and Simpson, 1978a,b; ChuWang and Oppenheim, 1978a,b; Oppenheim et al., 1978). Motoneurons are especially vulnerable to target deprivation, with only $10 \%$ of limb motoneurons surviving the cell death period (Hamburger, 1958; Oppenheim et al., 1978). Our results indicate that trkC + sensory neurons are similarly vulnerable to target deprivation, which accounts for the pronounced loss of VL neurons in response to limb bud deletion (Hamburger and LeviMontalcini, 1949; Carr and Simpson, 1978b). Similarly, relatively few trkC + neurons normally survive in thoracic DRG, which also exhibit a dramatic loss of VL neurons during normal development (Hamburger and Levi-Montalcini, 1949). The fact that many VL neurons are trkC + and trkA-negative may also account for the limited effectiveness of NGF in saving these neurons after limb bud deletion (Hamburger and Yip, 1984).

NT3 treatment blocked the loss of trkC + neurons induced by target deprivation and increased the survival of trkC + neurons in ganglia with normal target fields. Chronic treatment with NT3 during the cell death period selectively rescued trkC + sensory neurons in a dose-dependent manner without significantly altering the survival of trkA + or trkB + DRG neurons. NT3 rescued a normal complement of trkC + neurons in DRG that were deprived of developing limb targets. In addition, NT3 caused a twofold increase in trkC + neurons in DRG with normal limb targets and a fourfold increase in thoracic DRG. Given that the peripheral targets of these ganglia were presumably normal, these results strongly suggest that NT3 is normally present in limiting quantities in target tissues. Similar conclusions have been made based on the effects of gene dosage in NT3-deficient mice (Ernfors et al., 1994). Our results suggest further that in the chick, limb tissues normally provide more NT3 than do the targets of thoracic DRG. They also demonstrate that thoracic DRG can produce as many trkC + neurons as normal lumbar DRG, given an adequate source of NT3.

Several lines of evidence indicate that many of the trkC + neurons rescued by NT3 are, in fact, muscle spindle afferents. First, limb bud deletion eliminated most trkC + neurons and most Ia collaterals within the lumbar spinal cord. These effects were blocked by NT3 treatment, which restored both the trkC + population and the Ia projection. Second, NT3 treatment increased the trkC + population in thoracic DRG and also increased Ia fibers within the thoracic spinal cord. Third, many (if not all) of the Ia collaterals that project to the ventral spinal cord in control embryos are trkC+, and these projections were also increased by NT3. Although we cannot rule out the possibility that some of the trkC + neurons had other phenotypes, many of these neurons exhibited both an antigenic marker and spinal projections that are characteristic of muscle spindle afferents.

It is also notable that Ia collaterals projected to the ventral horn despite the absence of most limb motoneurons, the central targets of these fibers. Limb bud deletion causes massive death of these motoneurons, which is not prevented by NT3 (J. Calderó, D. Prevette, R. Oakley, and R. Oppenheim, unpublished observations). These results suggest that limb motoneurons, a potential central source of NT3, are probably not essential for the projection of Ia collaterals. 


\section{Differential effects of limb deletion and NT3 on other classes of sensory neurons}

In contrast to the trkC + population, other classes of sensory neurons were less sensitive to the absence of limb targets. The trkB + population was only marginally affected by the deletion. Some of these neurons are likely to be visceral afferents, because they project into the sympathetic chain. Indeed, in the rat, most visceral afferents coexpress trkA and trkB (McMahon et al., 1994). Limb bud deletion therefore would not be expected to deprive these neurons of their normal targets. In mammals, some visceral afferents are dependent on target-derived BDNF for survival (Hertzberg et al., 1994). Alternatively, trkB + neurons may be supported by autocrine mechanisms (Acheson et al., 1995). Although we did detect a significant loss of trkA+ neurons, $\sim 65 \%$ of these neurons survived in the absence of limb targets, in agreement with earlier studies (Hamburger and Levi-Montalcini, 1949; Carr and Simpson, 1978b). At least some of these neurons project to cutaneous targets in the body wall via the dorsal ramus, whereas others project aberrantly to the tail (R. Oakley and R. Oppenheim, unpublished observations).

Disruption of the NT3 gene results in the loss of many types of sensory neurons, including muscle spindle afferents (Ernfors et al., 1994; Fariñas et al., 1994; Tessarollo et al., 1994; Airaksinen et al., 1996). Further analysis of these mutants (Kucera et al., 1995; Elshamy and Ernfors, 1996; Fariñas et al., 1996; White et al., 1996) in combination with studies using function-blocking antibodies (Gaese et al., 1994; Oakley et al., 1995; Lefcort et al., 1996) have defined two distinct time periods when NT3 is required. Most types of sensory neurons require NT3 during early gangliogenesis, before the onset of target-dependent cell death. In addition, muscle spindle afferents have a specific, ongoing requirement for NT3 during the cell death period. Recent studies using transgenic mice indicate that NT3 is expressed within somites near the DRG during gangliogenesis and is expressed later in developing limb tissue as axons invade the limb (Fariñas et al., 1996). Our surgical manipulations presumably do not eliminate somitic sources but should only eliminate limb-derived NT3. In addition, we assayed the effects of NT3 treatment only at the end of the cell death period. If NT3 treatment lead to an initial increase in the survival of other classes of neurons, the effect would likely be short-lived because of subsequent target-dependent cell death. These considerations may explain the limited effects of our manipulations on other classes of sensory neurons.

\section{Muscle spindle afferents require NT3 from peripheral sources}

Our results also address the relative importance of different sources of NT3 during the period of target-dependent cell death. NT3 mRNA is expressed in developing muscle, muscle spindles, somites, and motoneurons and within the DRG itself (Shecterson and Bothwell, 1992; Henderson et al., 1993; Copray and Brouwer, 1994; Elkabes et al., 1994; Fariñas et al., 1996). The vulnerability of most trkC + neurons to the loss of peripheral targets, however, indicates that neither local sources of NT3 (from DRG and somite) nor autocrine mechanisms are sufficient to support the vast majority of trkC + neurons during this period. These findings demonstrate the physiological importance of NT3 derived from peripheral sources during this period, as suggested previously from antibody blocking studies (Oakley et al., 1995). One likely explanation of these results is that spindle afferents are dependent on muscle-derived NT3; however, because motoneurons also die after limb bud deletion, an alternative explanation is that sensory neurons are normally supported by NT3 derived from the axons of motoneurons.

\section{NT3 and the specification of muscle spindle afferents}

Previous experiments in the frog have shown that signals derived from limb muscle can determine the identity of sensory neurons. These studies showed that limb muscle could promote the development of muscle spindle afferents in thoracic DRG, which do not normally produce neurons of this phenotype. Moreover, these neurons made connections with motoneurons that were appropriate for the specific muscle that was supplied (Frank and Westerfield, 1982; Smith and Frank, 1987). Thus, signals from limb muscle can determine both the general phenotype of sensory neurons (i.e., muscle spindle afferent) and which motoneurons they will choose as synaptic partners. The results reported here demonstrate that NT3 can promote the differentiation of muscle spindle afferents, despite the absence of other limb-derived signals. NT3 can therefore mimic the effects of limb muscle at least in specifying the muscle spindle afferent phenotype. Thus, NT3 signaling could account for the development of these neurons in foreign (thoracic) DRG in the frog; however, our experiments do not examine the problem of the specification of synaptic partners, which probably depends on other mechanisms. We suggest that sensory neuron specification involves at least two stages, with neurotrophins influencing general phenotype and other factors, possibly specific to individual limb muscles (Wenner and Frank, 1995), influencing the choice of synaptic partners.

How might NT3 be involved in specifying the muscle spindle afferent phenotype? Two distinct mechanisms bear consideration. First, NT3 might act simply as a survival factor, promoting the survival of sensory neurons predetermined to become spindle afferents if only they can survive. This selective model is consistent with the well documented survival effects of NT3, but it also posits the existence of a subpopulation of sensory precursors that are committed to be spindle afferents, a proposition for which there is currently little evidence. Alternatively, NT3 might play an instructive role, with the activation of trkC altering the pattern of gene expression in uncommitted precursors. This model is consistent with the observation that most immature sensory neurons express trkC protein and respond to NT3 (Lefcort et al., 1996). It will be important to distinguish experimentally between these alternative models of sensory neuron specification.

\section{REFERENCES}

Acheson A, Conover JC, Fandi JP, Dechiara TM, Russell M, Thadani A, Squinto SP, Yancopoulos GD, Lindsay RM (1995) A BDNF autocrine loop in adult sensory neurons prevents cell death. Nature 374:450-453. Airaksinen MS, Klotzenburg M, Lewin GR, Masu Y, Helbig C, Wolf E, Brem G, Toyka KV, Thoenen H, Meyer M (1996) Specific subtypes of cutaneous mechanoreceptors require NT3 following peripheral innervation. Neuron 16:287-295.

Carr VM, Simpson SB (1978a) Proliferative and degenerative events in the early development of chick dorsal root ganglia: normal development. J Comp Neurol 182:727-740.

Carr VM, Simpson SB (1978b) Proliferative and degenerative events in the early development of chick dorsal root ganglia: responses to altered peripheral fields. J Comp Neurol 182:741-756.

Chu-Wang I, Oppenheim RW (1978a) Cell death of motoneurons in the chick embryo spinal cord I. J Comp Neurol 177:33-58.

Chu-Wang I, Oppenheim RW (1978b) Cell death of motoneurons in the chick embryo spinal cord II. J Comp Neurol 177:59-86.

Clarke PGH, Oppenheim RW (1995) Neuron death in vertebrate development: in vivo methods. In: Methods in cell biology, Vol 46, cell death. (Schwartz LM, Osborne BA, eds), pp 277-321. New York: Academic. Copray JC, Brouwer N (1994) Selective expression of neurotrophin-3 
messenger RNA in muscle spindles of the rat. Neuroscience 63:1125-1135.

Crowley C, Spencer SD, Nishimura MC, Chen KS, Pitts-Meek S, Armanini MP, Ling LH, McMahon SB, Shelton DL, Levinson AD, Phillips HS (1994) Mice lacking nerve growth factor display perinatal loss of sensory and sympathetic neurons yet develop basal forebrain cholinergic neurons. Cell 76:1001-1011.

DiCicco-Bloom E, Friedman WJ, Black IB (1993) NT3 stimulates sympathetic neuroblast proliferation by promoting precursor survival. Neuron 11:1011-1111.

Elkabes S, Dreyfus CF, Scharr DG, Black IB (1994) Embryonic sensory development: local expression of neurotrophin-3 and target expression of nerve growth factor. J Comp Neurol 341:204-213.

Elshamy WM, Ernfors P (1996) A local action of neurotrophin-3 prevents the death of proliferating sensory neuron precursor cells. Neuron 16:963-972.

Ernfors P, Lee KF, Kucera J, Jaenisch R (1994) Lack of neurotrophin-3 leads to deficiencies in the peripheral nervous system and loss of limb proprioceptive afferents. Cell 77:503-512.

Fariñas I, Jones KR, Backus C, Wang XY, Reichardt LF (1994) Severe sensory and sympathetic defects in mice lacking neurotrophin-3. Nature 369:658-661.

Fariñas I, Yoshida CK, Backus C, Reichardt LF (1996) Lack of neurotrophin-3 results in death of spinal sensory neurons and premature differentiation of their precursors. Neuron 17:1065-1078.

Frank E, Westerfield M (1982) The formation of appropriate central and peripheral connections by foreign sensory neurones of the bullfrog. J Physiol (Lond) 324:495-505.

Gaese F, Kolbeck R, Barde YA (1994) Sensory ganglia require neurotrophin-3 early in development. Development 120:1613-1619.

Garner AS, Large TH (1994) Isoforms of the avian trkC receptor: a novel kinase insertion dissociates transformation and process outgrowth from survival. Neuron 13:457-472.

Garner AS, Menegay HJ, Boeshore KL, Xie XY, Voci JM, Johnson JE, Large TH (1996) Expression of trkB receptor isoforms in the developing avian visual system. J Neurosci 16:1740-1752.

Hamburger V (1958) Regression versus peripheral control of differentiation in motor hypoplasia. Am J Anat 102:365-402.

Hamburger V (1975) Cell death in the development of the lateral motor column of the chick embryo. J Comp Neurol 160:535-546.

Hamburger V, Hamilton HL (1951) A series of normal stages in the development of the chick embryo. J Morphol 88:49-92.

Hamburger V, Levi-Montalcini R (1949) Proliferation, differentiation and degeneration in the spinal ganglia of the chick embryo under normal and experimental conditions. J Exp Zool 111:457-501.

Hamburger V, Yip J (1984) Reduction of experimentally induced neuronal death in spinal ganglia of the chick by nerve growth factor. J Neurosci 4:767-774.

Hamburger V, Yip J, Brunso-Bechtold JK (1981) Neuronal death in the spinal ganglia of the chick embryo and its reduction by nerve growth factor. J Neurosci 1:60-71.

Henderson CE, Camu W, Mettling C, Gouin A, Poulsen K, Karihaloo M, Rullamas J, Evans T, McMahon SB, Armanini MP, Burkemeier L, Phillips HS, Rosenthal A (1993) Neurotrophins promote motor neuron survival and are present in embryonic limb. Nature 363:266-270.

Hertzberg T, Fan G, Finley JCW, Erickson JT, Katz DM (1994) BDNF supports mammalian chemoafferent neurons in vitro and following peripheral target removal in vivo. Dev Biol 166:801-811.

Honig MG, Hume RI, (1986) Fluorescent carbocyanine dyes allow living neurons of identified origin to be studied in long term cultures. J Cell Biol 103:171-187.
Kalcheim C, Carmeli C, Rosenthal A (1992) Neurotrophin-3 is a mitogen for cultured neural crest cells. Proc Natl Acad Sci USA 89:1661-1665.

Klein R, Silos-Santiago I, Smeyne RJ, Lira SA, Zhang L, Snider WD, Barbacid M (1994) Disruption of the neurotrophin-3 receptor gene trkC eliminates Ia muscle afferents and results in abnormal movements. Nature 368:249-251.

Kucera J, Fan G, Jaenisch R, Linnarsson S, Ernfors P (1995) Dependence of developing group Ia afferent on neurotrophin-3. J Comp Neurol 363:307-320.

Lefcort F, Clary DO, Rusoff AC, Reichardt LF (1996) Inhibition of the NT-3 receptor trkC, early in embryogenesis, results in severe reductions in multiple subpopulations in the dorsal root ganglia. $\mathrm{J}$ Neurosci 16:3704-3713.

McMahon SB, Armanini MP, Lanway LH, Phillips HS (1994) Expression and coexpression of trk receptors in subpopulations of adult primary sensory neurons projecting to identified peripheral targets. Neuron 12 : 1161-1171.

Oakley RA, Garner AS, Large TH, Frank E (1995) Muscle sensory neurons require neurotrophin-3 from peripheral tissues during the period of normal cell death. Development 121:1341-1350.

Ockel M, Lewin GR, Barde YA (1996) In vivo effects of neurotrophin-3 during sensory neurogenesis. Development 122:301-307.

Oppenheim RW, Chu-Wang IW, Madedrut JL (1978) Cell death of motoneurons in the chick embryo spinal cord III. The differentiation of motoneurons prior to their induced degeneration following limb bud removal. J Comp Neurol 177:87-112.

Ruit KG, Elliott JL, Osborne PA, Yan Q, Snider WD (1992) Selective dependence of mammalian dorsal root ganglion neurons on nerve growth factor during embryonic development. Neuron 8:573-587.

Shecterson LC, Bothwell M (1992) Novel roles for neurotrophins are suggested by BDNF and NT-3 mRNA expression in developing neurons. Neuron 9:449-463.

Smeyne RJ, Klein R, Schnapp A, Long LK, Bryant S, Lewin A, Lira SA, Barbacid M (1994) Severe sensory and sympathetic neuropathies in mice carrying a disrupted trk/ NGF receptor gene. Nature 368:246-248.

Smith CL, Frank E (1987) Peripheral specification of sensory neurons transplanted to novel locations along the neuraxis. J Neurosci 7:1537-1549.

Snider WD (1994) Functions of the neurotrophins during nervous system development: what the knockouts are teaching us. Cell 77:627-638.

Tessarollo L, Vogel KS, Palko SW, Reid SW, Parada LF (1994) Targeted mutation in the neurotrophin-3 gene results in a loss of muscle sensory neurons. Proc Natl Acad Sci USA 91:11844-11848.

Tosney KW, Landmesser LT (1984) Pattern and specificity of axonal outgrowth following varying degrees of chick limb bud ablation. J Neurosci 4:2518-2527.

Tosney KW, Landmesser LT (1985) Development of the major pathways for neurite outgrowth in the chick hindlimb. Dev Biol 109:193-214.

von Bartheld CS, Williams R, Lefcort F, Clary DO, Reichardt LF, Bothwell M (1996) Retrograde transport of neurotrophins from the eye to the brain in chick embryos: roles of p75 and trkB receptors. J Neurosci 16:2995-3008.

Wenner P, Frank E (1995) Peripheral target specification of synaptic connectivity of muscle spindle sensory neurons with spinal motoneurons. J Neurosci 15:8191-8198.

White FA, Silos-Santiago I, Molliver DC, Nishimura M, Phillips H, Barbacid M, Snider WD (1996) Synchronous onset of NGF and trkA survival dependence in developing dorsal root ganglia. J Neurosci 16:4662-4672.

Willis WD, Coggeshall RE (1991) Sensory mechanisms of the spinal cord. New York: Plenum. 